\title{
RESEARCH
}

Open Access

\section{Using a new HSPC senescence model in vitro to explore the mechanism of cellular memory in aging HSPCs}

\author{
Yongpin Dong ${ }^{1,2+}$, Chunni Guo ${ }^{3+}$, Wuxiong Zhou' ${ }^{1}$, Wenfang $\mathrm{Li}^{2^{*+}}$ and Lina Zhang ${ }^{1 *}$
}

\section{Abstract}

Background: Age-associated changes attenuate human blood system fun on the aging of hematopoietic stem and progenitor cells (HSPCs), manifested in human popu tions an increase in myeloproliferative disease and even leukemia; therefore, study on H. oneschnce bears great significance to treat hematopoietic-associated disease. Furthermore, the mechanism of HSP ag, ig is lacking, especially the cellular memory mechanism. Here, we not only reported a new HSPC senesce ce model in vitro, but also propose and verify the cellular memory mechanism of HSPC aging of the Po romb/Trithorax system.

Methods: HSPCs ( Lin $^{-}{ }^{-}-$-kit $^{+}$cells) were isolated and purit ${ }^{-}$by $r$ agnetic cell sorting (MACS). The proportions and cell cycle distribution of cells were determined by f.ow cyto, rry; senescence-related $\beta$-galactosidase assay, transmission electron microscope (TEM), and colon, formin $y$ unit (CFU)-mix assay were detected for identification of the old HSPC model. Proteomic tests and iNA-seq applied to analyze differential pathways and genes in the model cells. qPCR, Western blot (WB), ana hromath immunoprecipitation PCR (CHIP-PCR) were used to detect the gene expression of cell memory-re/ with shRNA interference.

Results: In the model old HSPCs, $\beta-9$ activ $y$, cell cycle, colony-forming ability, aging-related cell morphology, and metabolic pathway were sign ntly changed compared to the young HSPCs. Furthermore, we found the model HSPCs have more obvious agin y vian estations than those of natural mice, and IL3 is the major factor contributing to HSPC aging in the $\mathrm{m}$ l. We also observed dramatic changes in the expression level of PRC/TrxG complexes. After further explorin. the downs, iream molecules of PRC/TrxG complexes, we found that Uhrf1 and Topll played critical roles in HC ag , based on the HSPC senescence model.

Conclusions tho findings proposed a new HSPC senescence model in vitro which we forecasted could be used to preliminary scree, bre drugs of the HSPC aging-related hemopathy and suggested cellular memory mechanism of HSPC ains,

Kev ords: on scence model, HSPC, Cellular memory, TOPOlla, UHRF1

*Corres, ndence: zln_1250@163.com; liwenfangsh@163.com

${ }^{+}$Yongpin ong, Chunni Guo, Wenfang Li and Lina Zhang contributed equally to this work.

${ }^{2}$ Department of Emergency and Critical Care Medicine, Shanghai

Changzheng Hospital, The Second Military Medical University, Shanghai,

China

${ }^{1}$ Institute of Basic Medicine, Shanghai University of Traditional Chinese

Medicine, 1200 CaiLun Ave., Pudong, Shanghai 201203, China

Full list of author information is available at the end of the article

\section{BMC}

(c) The Author(s). 2021 Open Access This article is licensed under a Creative Commons Attribution 4.0 International License, which permits use, sharing, adaptation, distribution and reproduction in any medium or format, as long as you give appropriate credit to the original author(s) and the source, provide a link to the Creative Commons licence, and indicate if changes were made. The images or other third party material in this article are included in the article's Creative Commons licence, unless indicated otherwise in a credit line to the material. If material is not included in the article's Creative Commons licence and your intended use is not permitted by statutory regulation or exceeds the permitted use, you will need to obtain permission directly from the copyright holder. To view a copy of this licence, visit http://creativecommons.org/licenses/by/4.0/ The Creative Commons Public Domain Dedication waiver (http://creativecommons.org/publicdomain/zero/1.0/) applies to the data made available in this article, unless otherwise stated in a credit line to the data. 


\section{Introduction}

The mammalian blood system is a highly differentiated and dynamic; most blood cells are the most short-lived and quickly replaced within few days. It is established that most mature blood cells are constantly generated and replaced from hematopoietic stem cells (HSCs) through a series of lineage-committed hematopoietic progenitor cells (HPCs) [1], so mammals maintain hematopoiesis by the activity of thousands of hematopoietic stem and progenitor cells (HSPCs) [1-4]. Although the blood is the definitive self-renewing tissue of the body, it does not escape the aging process. The previous study indicated age-related alterations in the human blood system depend on hematopoietic stem and progenitor cells (HSPCs) aging [5-7]. Hematopoietic aging is manifested in human populations in the form of an increase in myeloproliferative disease, including leukemias, declining adaptive immunity, and greater propensity to anemia. Therefore, a study on hematopoietic stem and progenitor cells (HSPCs) senescence bears great significance to treat hematopoietic associated disease. Furthermore, stem cells are exposed to both intrinsic and extrinsic assault over their lifetime; thus, has been hypothesized that aging or functional fain of stem cells may limit tissue repair and renew 1, ther contributing to overall organismal aging an (hit span reduction [8]. Therefore, besides great sig. crance treat hematopoietic disease, a study on ISC/HSPC senescence also bears great significance to furthe elucidate the mechanisms of aging.

Aging hematopoietic stem an $1 \mathrm{P}$ itor cell model in vitro is an important latfor a to study HSC/HPC senescence and associ ted liseas o [9]. To date, there were some ways bu ayng HSC/HSPC models in vitro includi old an al models [10], busulfaninduced cell asing odel [11], radiation-induced cell aging $\bmod 1[12]$, and ert-butyl hydroperoxide (t-BHP)induced ce no hodel [13]. However, these ways were limite ither $v$ iong experimental periods or complicat ol eration steps. Our study proposed a quick and easy thou of obtaining aging HSPC in vitro.

Comp red with the other aging theories, the mechanism of HSC/HSPC aging remains less known. Besides the known players such as DNA damage, telomere shortening, and oxidative stress, cellular memory maybe very important in HSC aging process [14, 15]. During the development of multicellular organisms, cells become different from one another by a distinct use of their genetic program in response to transient stimuli, an example being lineage specification in hematopoiesis [16]. Long after such a stimulus has disappeared, cellular memory mechanisms still enable cells to "remember" their chosen fate over many cell divisions. Cellular memory is a dynamic balance between the Polycomb group
(PcG) and Trithorax group (TrxG) proteins, then their target genes [14, 17-19]. PcG and TrxG group proteins are essential epigenetic regulators that can maintain stable epigenetic memory of silent states (via $-\mathrm{CG}$ ) and active states (via TrxG) of their target gen $\mathrm{H}$ c verer, the mechanism of cellular memory including $\mathrm{T} / \mathrm{T}, x \mathrm{~K}$ system alteration that occurs in the $\mathrm{H}^{\prime} \mathrm{D} C$ aging, ocess remains less known. Our previous stua, dem snstrated that the gene expression of PcG and TrxG roteins was significantly altered in HSPCs in $^{-} \mathrm{c}^{-\mathrm{k}^{+}} \mathrm{I}^{+}$) of old mice [18]. In the present study, od o new HSPC aging model, we further expl ored th $\mathrm{Pc}$ G/TrxG proteins expression alteration a ia he hist ne methylation regulatory on their target genes DPOII and UHRF1.

\section{Materials ana va... is \\ Animals and majo yents}

Equal nu no of male and female C57BL/6J SPF mice were obta led from Shanghai Sippr-BK Experimental Animal Ce ter [Certificate No. SCXK (Shanghai) 2013001 Young mice were 4 weeks of age and $16-18 \mathrm{~g}$ in weigh, and old mice were 18 months of age and 25-30 g is eight.

\section{Reagents}

Red blood cell lysis buffer, SA- $\beta-$ Gal staining kit, and cell cycle detection kit were purchased from Beyotime Biotechnology Co.; Lineage (Lin) Cell Depletion kit and Anti-c-kit (CD117) MicroBead kit were purchased from Miltenyi Biotec Co.; TUNEL Apoptosis Detection Kit (Alexa Fluor 647) was purchased from Shanghai Yeasen Biotechnology Co.; RNA Extraction and Purification kit, Reverse Transcription, and Fluorescence Quantitative PCR kit were purchased from Takara Co. Stemspan Stem Cell Media and Mouse Colony-Forming Unit (CFU) Assays Using MethoCult ${ }^{\mathrm{ma}}$ were purchased from Stem cell Co.; mouse SCF, mouse IL-3, and mouse IL-6 were purchased from Novus Biologicals Co.; antiCD117-PE (3C11) was purchased from Miltenyi Biotec Co.; anti-H3K4me3 (C42D8), anti-H3K27me3 (C36B11), anti-Mll1 (C36B11), anti-Trx (C63C6), anti-Ezh2 (D2C9), and anti-Bmi1 (D42B3) were purchased from CST Co.; anti-Mel18 was purchased from Abcam Co.; lipofectamine 3000 was purchased from Invitrogen Co.; and Opti-MEM was purchased from GIBCO Co.

\section{Isolation and purification of HSPCs}

Mice were sacrificed by cervical dislocation. The femur was elevated, and the bone marrow was rinsed. The filtrate was centrifuged, and the pellet was suspended in red blood cell lysis buffer, centrifuged at $3000 \mathrm{rpm}, 5$ min. The precipitate was bone marrow mononuclear cells (MNCs) (Fig. 1a). MNCs were suspended in PBS containing EDTA and $0.5 \%$ BSA. Then, we got HSPC by 


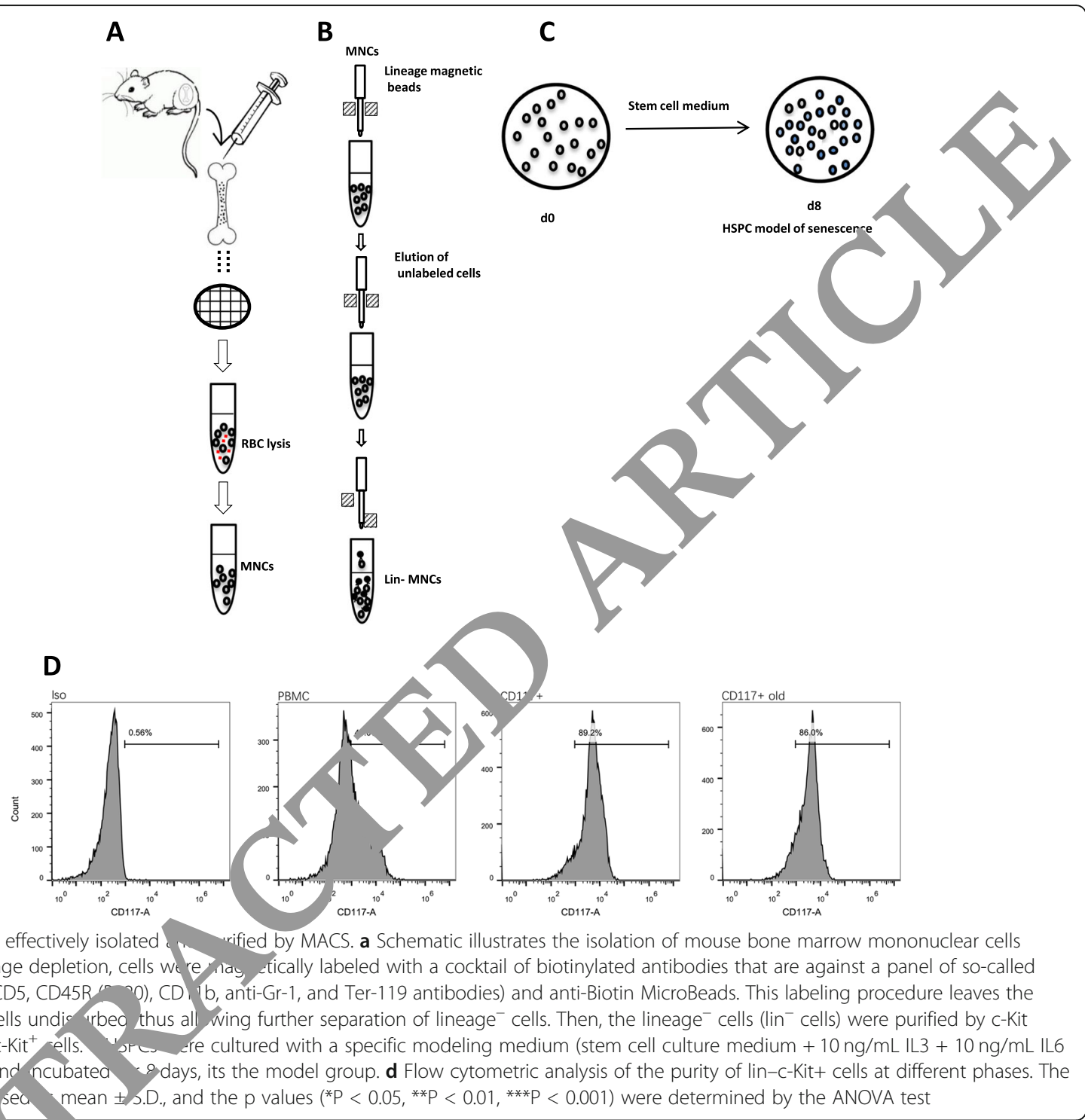

Fig. 1 HSPCS were effectively isolated rified by MACS. a Schematic illustrates the isolation of mouse bone marrow mononuclear cells (MNCs). b For lineage depletion, cells we re nay, ctically labeled with a cocktail of biotinylated antibodies that are against a panel of so-called lineage antigens (CD5, CD45R 0 ), CD, b, anti-Gr-1, and Ter-119 antibodies) and anti-Biotin MicroBeads. This labeling procedure leaves the lineage-negative cells undic rrbec thus all wing further separation of lineage ${ }^{-}$cells. Then, the lineage ${ }^{-}$cells (lin ${ }^{-}$cells) were purified by c-Kit MACS, namely lin c-Kit ${ }^{+}$ells. $+30 \mathrm{ng} / \mathrm{mL}$ SCF) and ncubatea odays, its the model group. $\mathbf{d}$ Flow cytometric analysis of the purity of lin-c-Kit+ cells at different phases. The results were expres sea. mean \pm S.D., and the $p$ values $\left({ }^{*} P<0.05\right.$, ${ }^{* *} P<0.01$, ${ }^{* *} P<0.001$ ) were determined by the ANOVA test

using Lin $k_{i}$ it munomagnetic beads sorting technique ith oe cell depletion kits and anti-c-Kit m; obe ids (Fig. 1b). CD117, also known as c-kit, stem cell 1 for receptor. It is expressed on the majority of hemato jietic progenitor cells, including multipotent hematopoietic stem cells, committed myeloid precursor cells, erythroid precursor cells, and lymphoid precursor cells. CD117 is also expressed on a few mature hematopoietic cells such as mast cells. So, CD117 MicroBeads (Miltenyi Biotec, Order no: 130-091-224) are developed for the isolation of hematopoietic stem/ progenitor cells and a few mature hematopoietic cells. The Lineage Cell Depletion Kit (Miltenyi Biotec, Order no: 130-090-858) is a magnetic labeling system for the depletion of mature hematopoietic cells, such as $\mathrm{T}$ cells, B cells, monocytes/macrophages, granulocytes, and erythrocytes and their committed precursors from bone marrow. So, after centrifugation and sorting of Lin-cKit+, the Lin-c-Kit+ cells of BMCs are considered to be hematopoietic stem cells/progenitor cells (HSPCs).

All the animal experiments were performed in compliance with the guidelines of the Animal Care and Use Committee of Shanghai University of Traditional Chinese Medicine.

\section{Flow cytometry analysis}

Cellular purity was detected with flow cytometer before and after sorting: to test HSPCs purity, $10^{6} \mathrm{MNCs}$ (unpurified) and $10^{6} \mathrm{Lin}^{-} \mathrm{c}-\mathrm{kit}^{+} \mathrm{MNCs}$ (purified) were collected. Ten microliters of CD117-PE was added to the cells. The cells were resuspended in FACS buffer and analyzed by flow cytometry using a Becton Dickinson Accuri $^{\text {in }}$ C6. 


\section{The establishment and identification of old HSPC model}

1) Young group: HSPCs were isolated from 4-weekold mice according to the steps above.

2) In vitro senescence model group: Young HSPCs were cultured with the modeling medium [Stemspan Stem Cell Media $+10 \mathrm{ng} / \mathrm{mL}$ interleukin 3 (IL3) $+10 \mathrm{ng} / \mathrm{mL}$ interleukin 6 (IL6) $+30 \mathrm{ng} / \mathrm{mL}$ stem cell factor (SCF)] for 8 days (Fig. 1c). The modeling medium was changed every 2 to 3 days.

3) Old mouse group: HSPCs were isolated from 18month-old mice according to the steps above.

\section{SA- $\beta$-gal staining}

HSPCs $(\sim 1,000,000$ cells) were collected on days $2,4,6$, and 8 . They were all fixed with $4 \%$ paraformaldehyde for $15 \mathrm{~min}$. The cells were incubated at $37^{\circ} \mathrm{C}$ without $\mathrm{CO}_{2}$ for $16 \mathrm{~h}$ in a $\beta$-galactosidase staining solution. The number of $\beta$-galactosidase-positive cells per 400 total cells was counted.

\section{Cell cycle}

HSPCs $(\sim 1,000,000$ cells) were collected, fixed ith /d $4 \%$ paraformaldehyde for $1 \mathrm{~h}$, and fixed with \% ethan overnight at $4{ }^{\circ} \mathrm{C}$. Cells were then incubated in propidium iodide staining solution (Beyotine) for $30 \mathrm{sn}$ at $37^{\circ} \mathrm{C}$ in the dark. The cell cycle dis ribution was analyzed by flow cytometry with the cars Express software.

\section{Mixed colony-forming _ it ( EII-Mi $/$ ) of HSPC culture}

Cells $\left(1.5 \times 10^{4}\right)$, ere ce ected and subjected to CFU culture: Cells wer diluted, in duplicate, with IMDM+ 2\% FBS and Metho ${ }^{\mathrm{tm}}$ GF M3434 medium to a final concentrat on of $5 \times 1 \mathrm{~s}^{3}$ per $35 \mathrm{~mm}$ dish. $0.3 \mathrm{~mL}$ of the diluted cel were added to $3 \mathrm{~mL}$ of MethoCult ${ }^{\mathrm{mm}}$ and mixf orous $1 \%$. The final cell mixture was dispensed inc ar $25 \mathrm{~mm}$ dish at a volume of $1.1 \mathrm{~mL}$ and incubated $37{ }^{\circ} \mathrm{C}$ in $5 \% \mathrm{CO}_{2}$ for 7 days. Photos were taken using al inverted microscope. Finally, we added $1 \mathrm{mg} /$ $\mathrm{mL}$-iodonitrotetrazolium violet to 24-well cells so as to take photos $24 \mathrm{~h}$ later. The number of CFU-Mix per 5 $\times 10^{3}$ cells represented the pluripotency of the HSPCs.

\section{Transmission electron microscope (TEM)}

Cells $(\sim 1,000,000$ cells) were prefixed with $2.5 \%$ glutaraldehyde and then dehydrated with an ethanol gradient series before being embedded in Epon812. Samples were cut into $50-70$-nm-thick sections by a microtome. All samples were observed under a transmission electron microscope (TEM) (JEM- 2100, JEOL, Japan).

\section{Isobaric tags for relative and absolute quantification (iTRAQ)}

Protein digestion and iTRAQ labeling were performed as described previously [20]. Briefly, $100 \mu \mathrm{g}$, protein from each sample was reduced, alkylate an then digested with sequence-grade modified tryp $\left(\mathrm{F}_{\mathrm{i}} \mathrm{O}\right.$ mega, Madison, WI) prior to labeling the of ne individual 8-plex-iTRAQ tags (Appli Bi systems, Framingham, MA). The peptid mixture as fractionated by high $\mathrm{pH}$ separation usi Ultim te 3000 system (Thermo Fisher Scientific, AA, connected to a reverse-phase column aDridg C18 column, $4.6 \mathrm{~mm} \times$ $250 \mathrm{~mm}, 5 \mu \mathrm{m}$, Wat $\mathrm{s}$ orporat on, MA, USA). Twelve fractions were separaced $b$, nnoLC and analyzed by online electrospr ta dem mass spectrometry. The experiments were po on an Easy-nLC 1000 system (Thermo Fisher So nific, MA, USA) connected to a QExactive titu anectrometer (Thermo Fisher Scientific, MA, USA equipped with an online nano-electrospray ion source. "EAKS DB was set up to search the UniProt mou database (ver.201711, 51946 entries) assuming the $d$ sestion enzyme trypsin. Differently expressed prot. were filtered if their fold changes were over 1.5 and contained at least 2 unique peptides with P (PEAKSQ) below 0.01 .

RNA-seq, library generation, and bioinformatics analysis HSPCs $(\sim$ 1,000,000 cells) were collected. Total RNA was isolated using the RNeasy mini kit (Qiagen, Germany). Strand-specific libraries were prepared using the TruSeq ${ }^{\circ}$ Stranded Total RNA Sample Preparation kit (Illumina, USA). Briefly, mRNA was enriched with oligo (dT) beads. Following purification, the mRNA is fragmented into small pieces using divalent cations under 94 ${ }^{\circ} \mathrm{C}$ for $8 \mathrm{~min}$. The cleaved RNA fragments are copied into first-strand cDNA using reverse transcriptase and random primers. This is followed by second-strand cDNA synthesis using DNA PolymeraseI and RNaseH. These cDNA fragments then go through an end repair process, the addition of a single "A" base, and then ligation of the adapters. The products are then purified and enriched with PCR to create the final cDNA library. Purified libraries were quantified by Qubit $^{\circ} 2.0$ Fluorometer (Life Technologies, USA) and validated by Agilent 2100 bioanalyzer (Agilent Technologies, USA) to confirm the insert size and calculate the mole concentration. Cluster was generated by cBot with the library diluted to $10 \mathrm{pM}$ and then were sequenced on the Illumina HiSeq X ten (Illumina, USA). The library construction and sequencing were performed at Shanghai Biotechnology Corporation, Shanghai, China. For GO enrichment analysis, selected differentially regulated genes between young group and old group HSPCs with a Fisher test-corrected $\mathrm{P}<0.05$ were analyzed on the 
Gene Ontology Consortium website (geneontology.org). Like GO enrichment, the association of the genes with different pathways was computed with the Kyoto Encyclopedia of Genes and Genomes (KEGG) (http:// www.genome.jp/kegg) databases. All data are representative of three independent experiments.

\section{TrxG/PcG disequilibrium Quantitative RT-PCR}

Quantitative real-time polymerase chain reaction (qRTPCR) was used to verify the gene expression of PCG proteins (Ezh2, Bmi-1, Eed, MEL18, Rae-28) and TRXG proteins (Mll, Trx). Total RNA extraction and reverse transcription were performed according to the manufacturer's instructions of the kits (9108/9109, Takara; RR047A, Takara). The A260/280 ratio of RNA was detected. The primers were designed and synthesized by Sango Biotech. The $\beta$-actin (internal control) primers were used. All primer sequences are listed: $\beta$-actin (internal control): 5'-AACGCAGCTCAGTAACA GT CC$3^{\prime}$ (forward), $\beta$-actin (internal control): 5' -GTACCACC ATGTACCCAGGC-3' (reverse); Ezh2: 5'-AGCAGTAA GAGCAGCAGCAA-3' (forward), Ezh2: 5' -TTCCT' 1 CC ATGC AA CACCCA-3' (reverse); Bmi-1: 5' - ' A C TGGGCAAACAGGAAGA-3' (forward) P ni-1:

GACTCTGGGAGTGACAAGGC-3' (reve se), 'Fed: 5'GCTCAGCCTGATCGAATG CT-3' (f $r$ ' rard), D $1 / 5^{\prime}$ TTGGCGATGGGATCGACTTC-3' (reverse); Mel18: 5'-TCCCC ATCTCCATTCTCCG ' 3' (forward), Mel18: 5' -ATACCCCCTGACA AGG ${ }^{\prime}$ - 3 ' (reverse); Rae-28: 5'-GCACAGATCTTC AL ' 'AAGG-3' (forward), Rae-28: 5'-GCAA GGCT 'CCAAGAGATTG-3' (reverse); Trx: 5'-TAA GO AGTC GCTTAGGGGAC-3' (forward), Trx: 5'-AG $1 \mathrm{~A}$ ATACCCAACTGCCA3' (reverse); and rll: 5'-A GCT TG TCTGTCTGGA TGG-3' (forward), Yll: 5' -CCCATGAGATTCCGGC ACTT-3' (everse).

SYBR gi n dye was used for real-time quantitative PCR 420 Takara). The $2^{-\Delta C t}$ method was used to $\mathrm{ca}^{\prime}$ lat the nRNA expression levels. $\Delta \mathrm{Ct}=\mathrm{Ct}_{\text {target }}$ gene $\mathrm{Ct}_{\text {internal }}$ control gene (where $\mathrm{Ct}$ is the cycle number when the fluorescence signal reaches the set threshold). The amplification parameters were $95^{\circ} \mathrm{C}$ for $30 \mathrm{~s}\left(95^{\circ} \mathrm{C}\right.$ for $5 \mathrm{~s}, 60^{\circ} \mathrm{C}$ for $\left.34 \mathrm{~s}\right)$ for 40 cycles. The analysis was performed with three biological replicates.

\section{Western blot}

Cells were lysed with RIPA lysis containing protease inhibitor. Cell lysates were collected and the total protein content was estimated by the Bradford method (BioRad). An aliquot of $70 \mu \mathrm{g}$ of protein extract was loaded in each lane and separated in a 10\% SDS-PAGE gel and electroblotted on a PVDF membrane. The membrane was then blocked with $4 \%$ BSA in $1 \times$ TBS and $0.1 \%$
TWEEN ${ }^{\circ} 20$, washed and probed using antibodies directed against Ezh 2(enhancer of zeste homolog 1), Bmi-1 (B lymphoma mo-MLV insertion region 2), Eed (embryonic ectoderm development), Mll (mix a lineage leukemia), MEL18 (melanoma nuclear prot 18, Rae28 (polyhomeotic-like protein 1), TOPOII ( $\mathrm{D}$ I to $\mathrm{po}$ isomerase 2-alpha), UHRF1 (ubiquit -like with PHD and ring finger domains 1), H3K2 ne3, $3 \mathrm{~K}_{4} \mathrm{ne} 3$, and GAPDH (endogenous loading control) vernight at room temperature. Blots were hen wa shed and incubated with (i) 1:2000 dilution of H. condary antibody for $2 \mathrm{~h}$ at room temperz cure. 'T protein bands were developed with chem $\mathrm{u}$. inescen reagents (Millipore). Relative band intensties $r$ determined by using the Image softwar

\section{Small int ving $R N$, (siRNA)}

Based on sicin ant downregulation of Bmi-1 and Trx in the mo el group, Bmi-1 and Trx were selected for on ' intertering RNA to validate their effect on the target $g$ he UHRF1 and TOPO and aging-related manifestiors. Three siRNAs targeting Bmi-1 and Trx were de signed and synthesized, respectively. Transfection: Cells were collected and resuspended in HSPCs medium without cytokines; $20 \mathrm{pM}$ of siRNA was added to $50 \mu \mathrm{l}$ of Opti-MEM serum-free medium; an equivalent amount of irrelevant siRNA was added as a negative control. Mixed the solution above before adding $400 \mu \mathrm{L}$ of cell suspension $\left(0.5-2 \times 10^{5}\right.$ per well in a 24-well plate) to it. $1.5 \mu \mathrm{l}$ of Lipofectamin 3000 (Invitrogen) reagent was added with $50 \mu \mathrm{l}$ of Opti-MEM. After $6 \mathrm{~h}$ of incubation at $37^{\circ} \mathrm{C} / 5 \% \mathrm{CO}_{2}$, the complexes were removed and the cells were incubated with cytokine-free media for up to $48 \mathrm{~h}$ after transfection. The mRNA expression levels of Bmi-1, Trx, TOPOII $\alpha$, and UHRF1 were detected by real-time fluorescence quantitative PCR. The protein expressions of Bmi-1, Trx, TOPOII $\alpha$, and UHRF1 were detected by Western blotting. We also performed SA- $\beta$-gal staining and CFU-Mix formation assay to observe aging manifestation.

\section{Chromatin immunoprecipitation (ChIP)}

The cells were fixed with formamide at a final concentration of $1 \%$ to cross-link the H3K4me3 or H3K27me3 with DNA. After the cells were broken by SDS lysis buffer, DNA was sonicated to a size of $250-1000$ bp (input DNA). The DNA protein complex was precipitated with specific antibodies (H3K4me3 or H3K27me3), absorbed onto the protein A agar, and decrosslinking. The precipitated DNA fragment was stored at $-20^{\circ} \mathrm{C}$ for a long time (this DNA fragment was named ChI Ped DNA). Fluorescent quantitative PCR was used to detect TOPOII $\alpha$ and UHRF1 levels of ChIPed DNA. 


\section{Statistical analysis}

The experimental data was expressed as a mean and standard deviation. Single-factor analysis of variance and one-way ANOVA were performed using SPSS 18.0. The LSD or Tamhane test was used to compare the differences between the two groups. $p<0.05$ was considered statistically significant.

\section{Results}

\section{Purification of HSPCs}

We detected HSPC purity by flow cytometry. The purity of $\mathrm{Lin}^{-} \mathrm{Kit}^{+}$cells was $91.7 \%$ (Fig. 1d) $(\mathrm{n}=10)$. It indicated that the sorted HSPCs are highly purified and suitable for subsequent experiments.

\section{The establishment of old HSPC model}

HSPCs isolated from 4-week-old mice were cultured with the modeling medium including Stemspan Stem Cell Media, $10 \mathrm{ng} / \mathrm{L}$ IL-3,10 ng/mL IL-6, and $30 \mathrm{ng} / \mathrm{mL}$ SCF for 8 days. At day 8 , flow cytometry was used to determine the ratio of HSPCs $\left(\mathrm{Lin}^{-} \mathrm{c}-\mathrm{Kit}^{+}\right)$. The results showed that the percentage of $\mathrm{Lin}^{-} \mathrm{c}-\mathrm{Kit}^{+}$cells at day 8 was $86 \%$ (Fig. 1d). It suggested HSPCs still have a nigh proportion at day 8 and enough for testing.

\section{The identification of old HSPC model}

To identify the old HSPC model, the flowing yeriments were performed: SA- $\beta$-gal stai ing, cell cycle distribution detection, colony-forming a ay, tr nsmission electron microscope (TEM), ar ${ }^{\wedge}$ RNA-suy bioinformatics analysis. We further identif to he comparative study on HSPCs isolated from ad mouse (18-monthold) and old model HS Cs.

\section{The percentage of $1-\beta$-gal si $n$-positive cells increased}

SA- $\beta$-gal (sen scen associated- $\beta$-galactosidase) is a hallmark $o$ aging that an yield a blue stain in the cytoplasm of $a_{\varepsilon}$ 'cell $[21,22]$. We found that the percentage $\sigma^{f} \sim \mathrm{A}-\beta-\mathrm{g}$ s ain-positive cells increased gradually at d? 2, 2, 6, ana 8 compared with the young group (Supplem tary rig.S1). Therefore, day 8 was chosen as the optimur time of modeling. The percentage of SA- $\beta$-gal stain-positive cells in the model group (day 8 ) and in the old mouse group were significantly higher than those in the young group (day0) (Fig. 2a, Table 1), $\mathrm{P}<0.01, \mathrm{P}<$ 0.05 . The percentage of SA- $\beta$-gal stain-positive in the model group (day 8) was significantly higher than that in the old mouse group (Table 1), $\mathrm{P}<0.01$. (Fig. 2a). It indicated that the senescence model group has more senescent HSPCs than the old mouse group.

\section{The percentage of G0/G1 phase cells increased}

Previous studies showed that senescent HSPCs were arrested in G0/G1 $[7,18]$. In the present study, we found that compared with the young group (41.93 $\pm 1.95 \%)$, the proportion of G0/G1 phase cells in the model group was significantly higher $(70.28 \pm 2.45 \%), \mathrm{P}<0.01$; the proportion of G0/G1 phase cells in old mo se group $(46.59 \pm 2.32 \%)$ was higher than the young o up 4193 $\pm 1.95 \%), \mathrm{P}<0.05$, but the degree of increase $<$ lo ver than the model group (Fig. 2b, Table 2 The prol ortion of PI $(S+G 2 / M)$ phase cells was s'rnifi ntly ecreased in the model group compared w the you, 0 group, $\mathrm{P}<$ 0.05 (Fig. 2b, Table 2). These sults showed that the senescence model HSPCs 3 ar in G0/G1.

\section{Colony-forming ability decre of}

The capacity tr for 1 CFU-mix decreased in HSPC aging process [7, 18, il ar study, young group HSPCs formed ruthroid $\mathrm{F}$ genitor cells (colony-forming uniterythroid $\left[1-\mathrm{F}_{\mathrm{j}}\right.$ and burst-forming unit-erythroid [BFU-E]), canuocyte/macrophage progenitor cells (colon-formin unit-granulocyte, macrophage [CFU-GM]), colo, -forming unit-granulocyte (CFU-G) and colony'ormi g unit-macrophage (CFU-M), multi-potential prog. lor cells (colony-forming unit-granulocyte, erythroid, nacrophage, megakaryocyte [CFU-GEMM]), B lymphocyte progenitor cells (colony-forming unit-pre-B [CFUpre-B]), whereas the model group HSPCs only occasionally formed CFU-G (Fig. 2c). Furthermore, p-iodonitrotetrazolium violet staining of CFU-mix experiment clearly showed that compared with the young group, model HSPCs displayed smaller and fewer colonies (Fig. 2c). The number of CFU-Mix colonies formed by old mouse HSPCs was also reduced than that of the young group, but the degree of reduction was lower than that of the model group. These results revealed that the capacity of colony formation of the model HSPCs decreases significantly.

\section{The ultrastructure of HSPCs changed}

In order to visualize age-related ultrastructure changes of HSPCs, we explored it by using the TEM method. It showed that the nuclear membrane of young HSPC was smooth and flat; there was homogeneous chromatin distribution and no or few inclusion bodies in the cytoplasm (Fig. 2d). However, the perinuclear cisternae of model HSPCs widened, and the chromatin edge aggregated. A large number of inclusion bodies appeared in the model HSPCs. The presence of inclusion body may be due to the aging of organelles that occurs when biomicromolecules are stored but not digested in the lysozyme, eventually accumulating in the cells to become brown liposarcoma [23, 24]. Old mouse HSPCs show similar but less morphologic changes than senescence model HSPCs (Fig. 2d and Supplementary Fig.S2). 


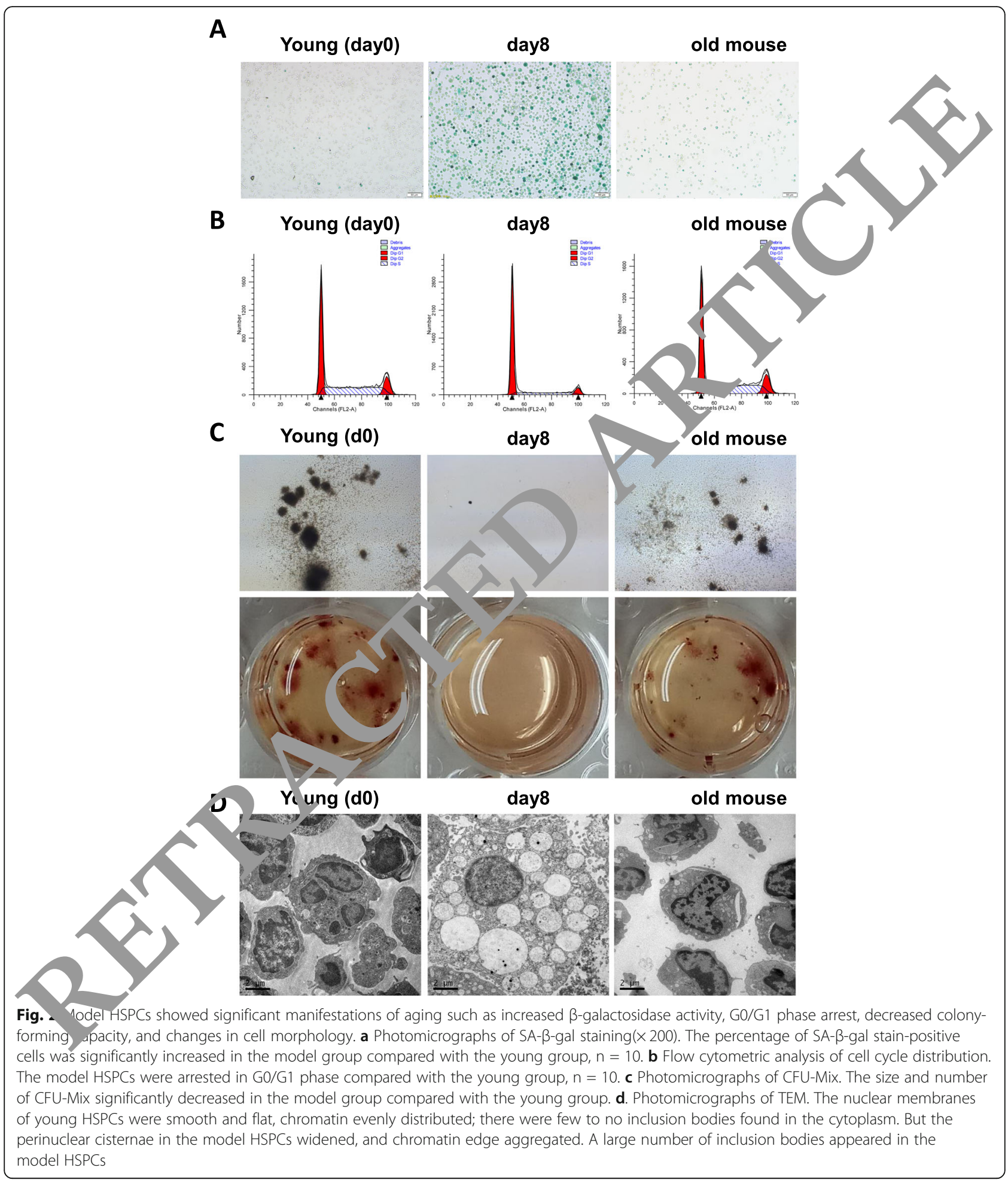

Age-related metabolic pathways changed by ITRAQ analysis In order to study the changes of age-related metabolic pathways, we performed quantitative proteomic analysis based on isobaric tags for relative and absolute quantitation (iTRAQ). The volcano plot (a) and the heatmap (b) was shown in Fig. 3. Gene Ontology (GO) analysis revealed that the aging process increased significantly in model HSPCs compared with the young group ( $p<0.01$; Fig. $3 c)$. GO and Kyoto Encyclopedia of Genes and Genomes (KEGG) analyses 
Table 1 Percentage of SA- $\beta$-gal stain-positive HSPCs (\% x $\pm s, n$ $=10$ )

\begin{tabular}{ll}
\hline Group & Percent \\
\hline Young group & $1.02 \pm 0.09$ \\
Model group & $56.4 \pm 5.21^{* *}$ \\
Old mouse group & $7.16 \pm 1.14^{*}$
\end{tabular}

${ }^{*} \mathrm{P}<0.05$, compared with the young group

${ }^{* *} \mathrm{P}<0.01$, compared with the young group

consistently showed that the most differentially expressed proteins between the model group and the young group were associated with glycolysis, lysosomal, ribosomal synthesis, and mRNA splicing $(p<$ 0.01; Fig. 3c, d, Fig.S3). Glycolysis and lysosomal metabolism were significantly increased whereas ribosomal synthesis, and mRNA splicing were significantly reduced in the model group compared with the young group (Table 3, Fig.S3). Glycolytic metabolism increased in model vs young was consistent with the result of increased glycolysis metabolism in the aging process shown by the previous study [25]. Lysosomal phagocytosis enhanced in model vs young was consistent with the electron microscopy data (Fig. 2 it may be due to a large number of damage' or ag cells and their metabolites, which are has cytosed by lysosomes. The data also show that DNA splicing-related proteins SR, hnRNP WBP11, splicing factor $3 \mathrm{~b}$, and U2AF1 were signific tly de reased in model vs young (Table 3 ). I indicate nat the expression of spliced mRNA was sig antly decreased. This conclusion is in lin with ecent research, which found that SF3B1, U2 F1 nutat ons led to an imbalance of hematopo; tic nctron $[26,27]$. The results manifested that any ag s-related metabolic pathways changed $\mathrm{n} n$ del vs young. In addition, STRI NG of iTP.AQ showe that the common target proteins of $P$ ami $y$ and TrxG family are UHRF1 and TOP I $\alpha$, a s. own in Fig. 3e. We validated it later in e p aner.

\section{Transcri, ome changes by RNA-seq analysis}

To identify transcriptome changes in the model group, we examined the expression of more than 16 , 800 genes using RNA-seq. This analysis revealed 3717 genes that were upregulated and 3931 genes that were

Table 2 Distribution of cell cycles of HSPCs $(x \pm s, n=5)$

\begin{tabular}{llll}
\hline Group & G0/G1 & G2/M & S \\
\hline Young group & $41.93 \pm 1.95$ & $12.38 \pm 0.20$ & $45.69 \pm 2.06$ \\
Model group & $70.28 \pm 2.45^{*}$ & $7.28 \pm 0.39^{*}$ & $22.45 \pm 1.57^{*}$ \\
Old mouse group & $46.59 \pm 2.32$ & $12.64 \pm 0.69$ & $40.77 \pm 2.15$ \\
\hline
\end{tabular}

${ }^{*} \mathrm{P}<0.05$, compared with the young group downregulated in the model group vs the young group, which is summarized as a scatter plot (Fig. 3f). As shown in Fig. 3g, the biological process of GO terms associated with the differentially expressed genes was related to aging and lysosomal ta dirm, ribosomal synthesis, and mRNA splicing. is re, alt was consistent with our proteomic analysis. When applied to the Up-with-Age gene list, an aysis revealed a large number of er riched ca yories that have been linked to aging in reneral such as NOmediated signal transduc on, stress response (protein folding) and the flammatory response, whereas categories nl hed for Down-with-Age genes often included those inv ved in the preservation of genomic integ ity, uch as chromatin remodeling and DNA repair (t the result was consistent with Margaret A. Go 'oll's study [28]. A small handpicked li it hoyn in Table 4 showed the most significant $d$ fere inces in genes in the model group and thn young youp, consistent with the data of Margaret A. 4 odell [28].

\section{1. actor of driving the model HSPC aging}

To explore what is the main factor of driving the model HSPC aging we treated the cells with IL3 (10 $\mathrm{ng} / \mathrm{mL}$ ), IL6 $(10 \mathrm{ng} / \mathrm{mL})$, SCF $(30 \mathrm{ng} / \mathrm{mL})$, media (no IL3, IL6, SCF) or together with each other. We evaluate the aging effects with SA- $\beta$-gal staining and the CFU-Mix method. The results showed a significant decrease in colony-forming ability and increase in SA- $\beta$-gal activity at IL3 groups compared with the control (medium) group (Fig. 4a, i, j). The cells cultured with IL3 alone or together with IL3 were mainly SA- $\beta$-gal-positive and showed a significant decrease in the capacity of colony formation (Fig. $4 a-d$, $i, j)$. There was no significant change in the colonyforming ability and SA- $\beta$-gal activity at the cells cultured with IL6,SCF alone or together with IL6,SCF compared with the control (medium) group (Fig. 4ej). The previous study reported that the growth of HSC in vitro is strictly dependent on growth factors, in particular, IL3 [29]. López et al. demonstrate that IL-3 contributes to cell survival under oxidative stress, a prominent feature in the aging process [30]. In our study, contrary to these researches that IL3 is a positive factor of HSC growth in vitro or antiaging of cells, our study showed IL3 can lead HSPC to senescence. However, our study was consistent with Frelin et al.'s study that showed Grb2 was positioned as a key adaptor integrating various cytokines response in cycling HSPC by IL3 signaling pathway [31]. Base on the previous researches and our study, we speculated that IL3 could play a role in activating HSPC senescence. 


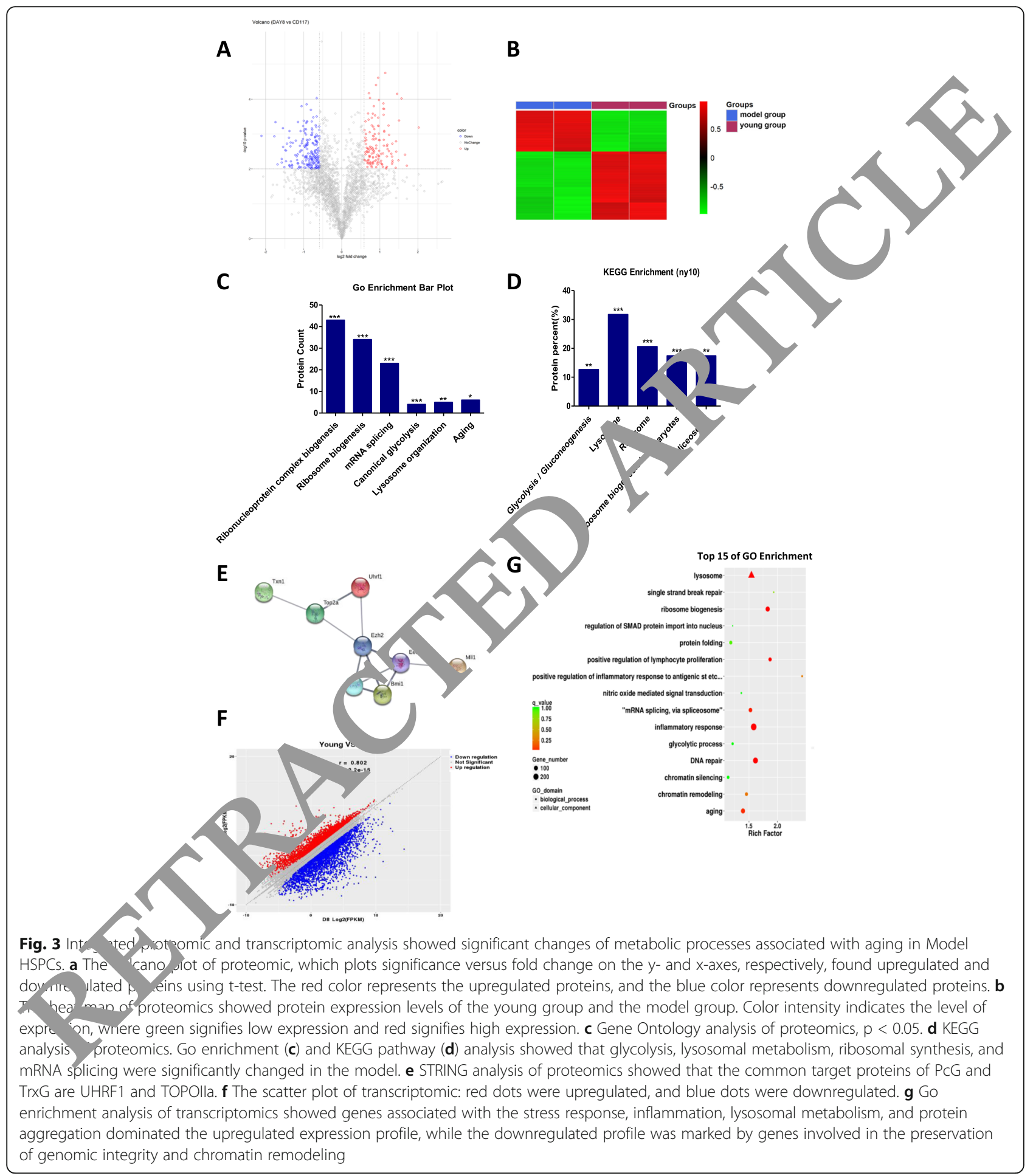

\section{Polycomb/Trithorax system disturbance in HSPC aging process}

To understand how cellular memory regulates HSPC aging, we examined the gene expressions of PCG (Ezh2, Bmi-1, Eed, Rae-28, Mel18) and TrxG (Mll and Trx) with real-time PCR and Western blot. Furthermore, we explored the target genes of the PcG/TrxG system and identified two genes, UHRF1/TOPOIIa.

The changes of Polycomb/Trithorax genes mRNA expression The A260/280 ratio of RNA extracted from the HSPCs was 1.8-1.9, indicating high purity of RNA. 
Table 3 Differently expressed genes in the KEGG metabolic pathway (model group/young group)

\begin{tabular}{|c|c|c|c|}
\hline Accession & Description & Gene name & Fold change ratio \\
\hline G3UW4 & Hexokinase 1 & $\mathrm{Hk} 1$ & 1.2 \\
\hline Q3TRM8 & Hexokinase-3 & Hk3 & 1.57 \\
\hline P12382 & ATP-dependent 6-phosphofructokinase & Pfkl & 0.88 \\
\hline Q9WUA3 & ATP-dependent 6-phosphofructokinase platelet type & Pfkp & 1.66 \\
\hline P52480 & pyruvate kinase & Pkm & \\
\hline P35486 & Pyruvate dehydrogenase E1 component subunit alpha & Pdha1 & \\
\hline O70370 & Cathepsin S & Ctss & 1.87 \\
\hline O89023 & Tripeptidyl-peptidase 1 & TPP1 & 1.71 \\
\hline O35114 & Lysosome membrane protein 2 & & 1.82 \\
\hline P11438 & Lysosome-associated membrane glycoprotein 1 & & 1.91 \\
\hline P17047 & Lysosome-associated membrane glycoprotein 2 & & 1.42 \\
\hline P50516 & V-type proton ATPase catalytic subunit A & & 1.94 \\
\hline Q9Z204 & Heterogeneous nuclear ribonucleoproteins C1/C2 & & 0.63 \\
\hline Q923D5 & WW domain-binding protein 11 & & 0.6 \\
\hline Q921M3 & Splicing factor $3 \mathrm{~b}$ subunit 3 & SF3B3 & 0.81 \\
\hline Q3UJBO & Splicing factor $3 \mathrm{~b}$ subunit 2 & SF3B2 & 0.62 \\
\hline Q9D883 & Splicing factor & U2af1 & 0.5 \\
\hline Q97204 & Heterogeneous nuclear ribonucleop & Hnrnpc & 0.63 \\
\hline
\end{tabular}

The mRNA levels of Ezh2, Bmi-1, and Eec Mll in the model group were significantly lo we than at in the young group, $p<0.01$ (Fig. $5 \mathrm{a}$ d); There are no significant differences in the mRNA vvels of Mel18, Rae-28, and Trx (Fig. 5e-g).
The changes of Polycomb/Trithorax genes protein expression

The protein levels of Ezh2, Bmi-1, Eed, and Trx in model HSPCs were significantly lower than young HSPCs (Fig. 5h). Mll was significantly increased in the

Table 4 Differently exprec ed $g$. nes se -cted (model group/young group)

\begin{tabular}{|c|c|c|c|}
\hline Symbol & G.a na. & $\log _{2} \mathrm{FC}$ & Significance \\
\hline$\overline{X a b 2}$ & in 2 & -1.02 & DNA repair \\
\hline Sirt3 & & -1.04 & Chromatin silencing \\
\hline Sirt & & -1.57 & Chromatin silencing \\
\hline Rad5: & AD52 homolog & -1.62 & DNA repair \\
\hline & X-ray repair comp. defective repair in C. hamster cells 3 & -2.32 & DNA repair \\
\hline Eng & Endoglin & -2.81 & TGF-b regulates HSPCs pool size \\
\hline Blm & Bloom syndrome homolog & -1.48 & DNA repair \\
\hline Sirt & Sirtuin 2 & -1.57 & Chromatin silencing \\
\hline App & Amyloid beta precursor protein & 4 & Alzheimer disease, stress response \\
\hline Selp & Platelet-selectin & 2.47 & Inflammation, adhesion \\
\hline Ctsb & Cathepsin B & 3.56 & APP processing, Alzheimer \\
\hline Ctsc & Cathepsin C & 4.85 & Proteolysis, inflammation \\
\hline Icam1 & Intercellular adhesion 1 & 4.2 & Cell-cell adhesion, inflammation \\
\hline Ctss & Cathepsin S & 7.4 & Proteolysis, inflammation \\
\hline Cct6a & Chaperonin subunit 6a (zeta) & 1.34 & Protein folding \\
\hline Dnajb6 & DnaJ (Hsp40) homolog B6 & 2.8 & Protein folding \\
\hline TIr4 & Toll-like receptor 4 & 2.08 & Inflammation \\
\hline
\end{tabular}


A
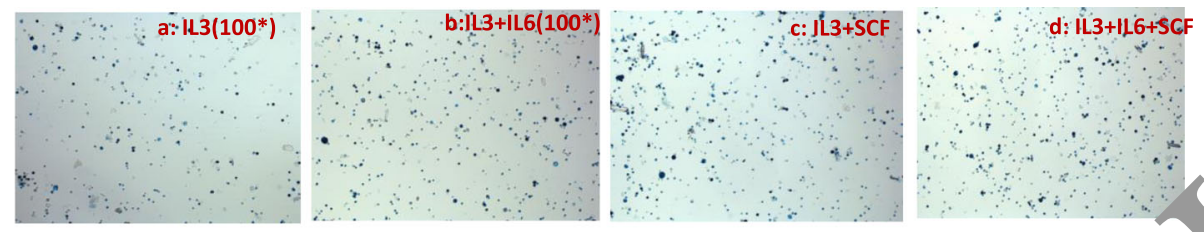

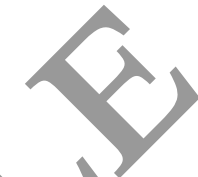
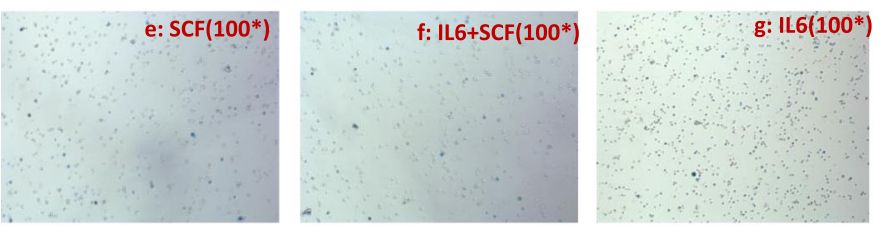

B
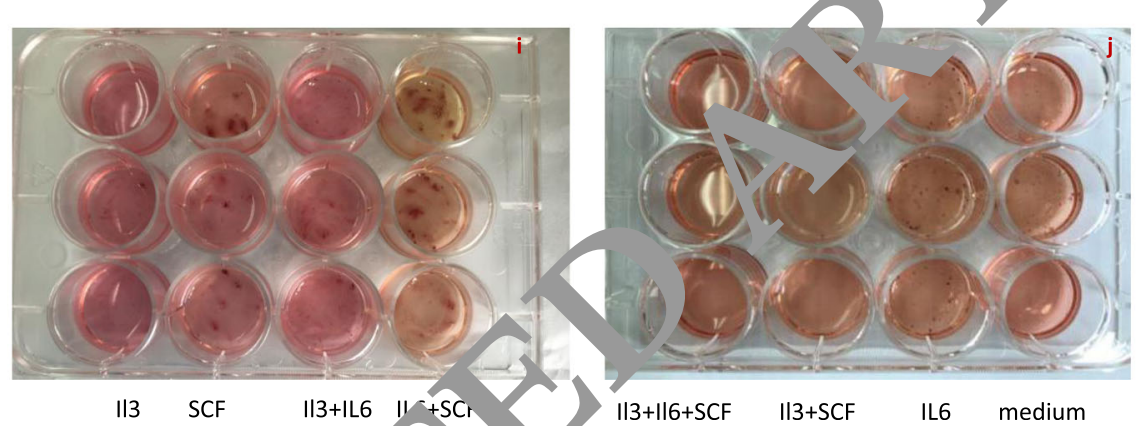

Fig. 4 The factors driving the model HSPC aging. $\mathbf{a}-\mathbf{h}$, tomicrogr together with IL3 were mainly SA- $\beta$-gal-positive. Ther was signifieant change in the SA- $\beta$-gal activity at the IL6,SCF alone group or together with the IL6,SCF group. i, j Photomicrographs of C.Mix. The is cultured with IL3 alone or together with IL3 showed a significant decrease in colony-forming ability. There was no significan change in the colony-forming ability at the IL6,SCF alone group or together with the IL6,SCF group

model group, $p<0.05$, (Fi $5 \mathrm{~h})$. 'I ne protein expressions of Mel18 and Rae-28 ere not sis, nificantly different in the two groups (Fig $-\mathrm{h}$ ). ne uara of STRING of iTRAQ might also pro. 'e us get genes of Polycomb/ Trithorax, UHKF1, a T TOPOII (Fig. 3e). The protein levels of $U_{1} \mathrm{RF} 1$ and OPOII $\alpha$ were significantly lower than young HCPS $p<0.05$. (Fig. 5h).

To ther vrore the possible histone methylation re lation of olycomb/Trithorax on the target genes, the lo ls or H3K4me3 (trimethylation of histone H3K4) and H3, $27 \mathrm{me} 3$ (trimethylation of histone H3K27) were examined. H3K4me3 was known to be involved in gene transcriptional activation which can be catalyzed by TrxG [32, 33], and H3K27me3 is involved in transcriptional repression which can be catalyzed by PcG [34, 35]. The total level of H3K27me3 or H3K4me3 was all significantly downregulated in the model group compared with the young group $(p<0.01)$ (Fig. 5l, j). The grayscale of Western blot showed that the ratio of $\mathrm{H} 3 \mathrm{k} 4 \mathrm{me} 3 / \mathrm{H} 3 \mathrm{k} 27 \mathrm{me} 3$ in the young group was 0.6 , whereas in the model group, it was 0.36 (Fig. 5i, k). It is not difficult to find the reduction of $\mathrm{H} 3 \mathrm{~K} 4 \mathrm{me} 3$ plays a leading role in the HSPC aging process. So, whether
TOPOII /UHRF1, which was significantly downregulated, was regulated by the general reduction of H3K4me3, or by a single factor, the reduction of H3K27me3 or H3K4me3 need to be further elucidated below in our study.

\section{H3K4me3 of TOPOIla and UHRF1 promoter decreased in model HSPC}

To further validate H3K27me3/H3K4me3 of Polycomb/ Trithorax on TOPOII $\alpha /$ UHRF1, we examined it with CHIP-PCR. The data showed that the level of H3K4me3 in TOPOII $\alpha$ or UHRF1 promoter was both decreased significantly in the model group (Fig. 6a, b), but there was no significant change in the level of H3K27me3 in TOPOII $\alpha$ or UHRF1(Fig. 6c, d). Therefore, we speculated that $\mathrm{H} 3 \mathrm{~K} 4 \mathrm{me} 3$, not $\mathrm{H} 3 \mathrm{~K} 27 \mathrm{me} 3$, downregulated TOPOII $\alpha /$ UHRF1.

\section{Knocking down Bmi-1/Trx downregulated TOPOIla/UHRF1 expression}

To further validate TOPOII $\alpha /$ UHRF1 was the target gene of PCG/TrxG, we studied the effect of knocking down Bmi-1 in PCG or Trx in TrxG on aging-related 

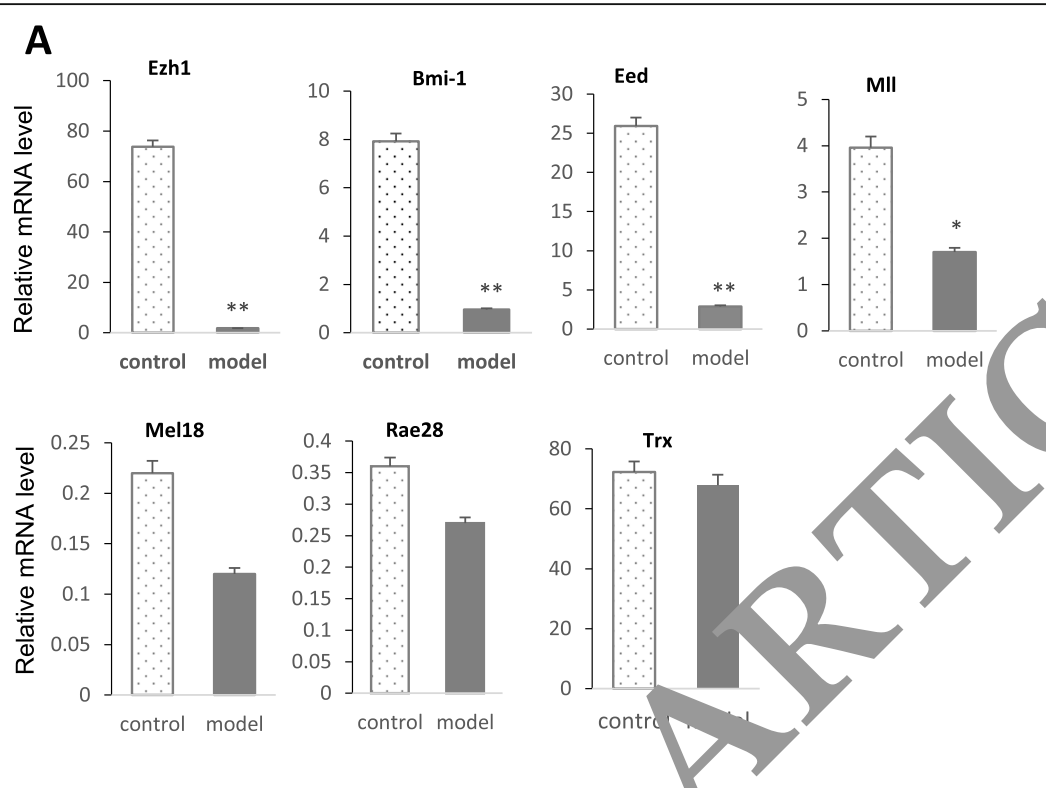

B
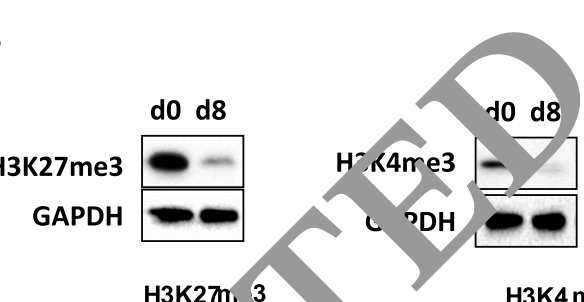

C

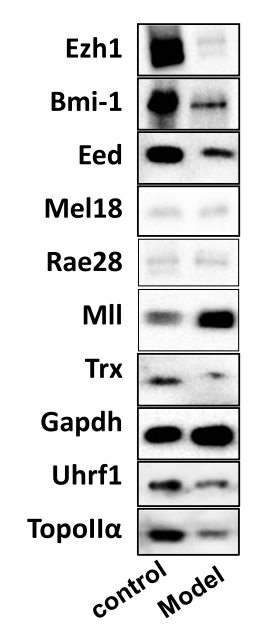

Fig. 5 Polycomb / sithora vstem disturbance in HSPC aging process. RT-PCR was applied to determine the transcription levels of PcG/TrxG genes (a). W/ stern blot was applied to determine the levels of PcG/TrxG proteins and TOP2a,URHF1 (c) and H3K4,H3K27 (b)

$\mathrm{m}$ ifes ations and the gene expressions of TOPOII $\alpha$ and TRFI. The results showed that the mRNA level and pro in level of Bmi-1 or Trx was both significantly decreased after being transfected with Bmi-1 or TrxsiRNA for $48 \mathrm{~h}$, respectively $(\mathrm{p}<0.05)$ (Fig. $7 \mathrm{a}-\mathrm{d}$ ), indicating that siRNA effectively knocked down Bmi-1 or Trx in HSPCs. The mRNA levels of TOPO2a and UHRF1 were both significantly decreased when Bmi-1 or Trx was knocked down, as shown in Fig. 6e, f, p < 0.05 . SA- $\beta$-gal-stained cells increased in the Bmi-1 or Trx knocked down group, but there was no significant difference (Fig. 7g, h and Supplementary Table.S1); we speculated that cell aging caused by stress need enough time; colony-forming ability of HSPCs significantly decreased in the Bmi-1 or Trx knocked down group compared with the control group, $\mathrm{P}<0.05$, (Fig. 5i, j). The results not only demonstrated TOPOII $\alpha$ and UHRF1 were the target genes of Bmi-1 or Trx in HSPCs, but also indicated Bmi-1 and Trx were important members of PCG/TrxG.

\section{Discussion}

Senescence HSPC model in vitro is an important platform to study HSPC senescence and screen the antiaging drug for hemopathy. Our study presented a quick and easy method of building senescence HSPC model in vitro with a 4-week mouse. The method had the advantages including shorter time requirements and easy operation. 

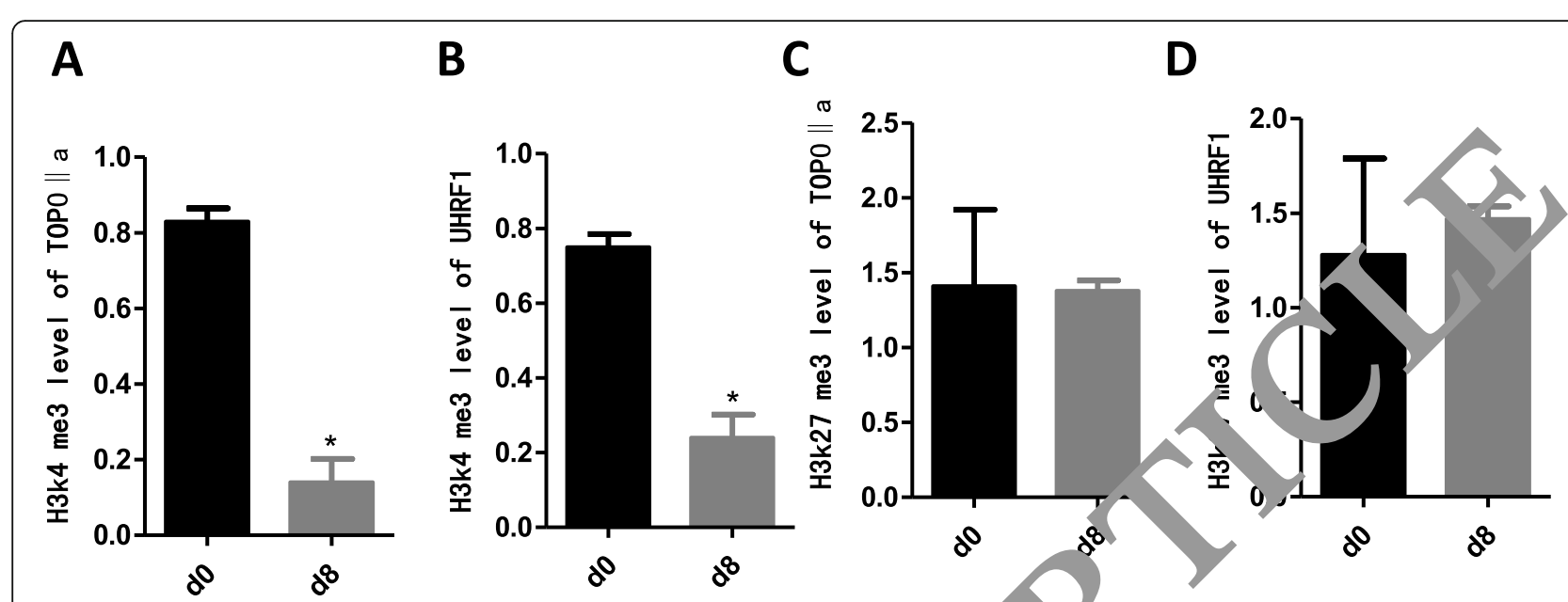

Fig. 6 CHIP-PCR showed H3K4me3 of TOPOlla and UHRF1 promoter decreased in senescent $\mathrm{H}_{\mathbf{3}}$. a, ne level of H3K4me3 in TOPOIla/UHRF1 promoter was decreased in aging HSPCs. c, d There was no significant change in the level of H3K $2 \mathrm{nn} 3$ in TOPOlla/UHRF1 promoter in aging HSPCS

Our senescence HSPC model showed a significant increase in senescence-related $\beta$-gal activity, cell cycle arrest, reduction in colony-forming ability of HSPCs agerelated changes in cell morphology, and age-r trd metabolic pathway. Furthermore, the mod el HSP showed more obvious aging manifestati n mpared with the HSPCs of natural aging mours so we eculated that this was a model of accele ating HSPC aging in vitro compared with in vivo.

Polycomb group (PcG) and Trithora soup (TrxG) are evolutionarily conserved cl ror modifying factors identified as histone - nethy ransferase complexes, which can methylate $\frac{1}{\text { ton }}$ lysin -specific sites of target proteins. The T/G, G system maintains the balance of cellular $p$. nory sys $m$ that prevents the change of stem cells ilent by antagonizing each other [36, 37]. In add cior in rec nt years they were found to have more wiac cont ol a plethora of cellular processes. This ction aversity is achieved by their ability to re late chronatin at multiple levels, ranging from modi. ng local chromatin structure to orchestrating the three-di Aensional organization of the genome. So, understanding the TrxG/PcG system is a fascinating challenge of critical relevance for biology and medicine [38]. PcG proteins assemble in multimeric complexes, PRC1 and PRC2 (Polycomb repressive complexes 1 and 2), and induce transcriptional repression of target genes through chromatin modifications such as H3K27me3 [39, 40]. Conversely, TrxG complex induce transcriptional activation of target genes through chromatin modifications such as H3K4me3 [41]. PRC1 consists of ph 1/Rae-28, Bmi-1, Mel-18, and other proteins in mammals [42]. The primary function of PRC1 is to label monoubiquitination of the 119th lysine site of histone H2A, then y recruit PRC2 complex. PRC2 consists of EeD,

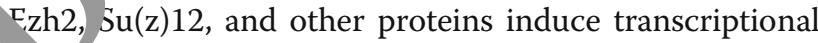
S. ression of target genes through chromatin modifications such as H3K27me3 and lysine26 on histone 1 (H1K26 me3) [43]. TrxG is mainly composed of Trx, Ashl, and Mll. The previous study indicated that TrxG and PcG proteins can co-occupy and modify chromatin. TrxG protein-deposited histone modifications such as methylation at H3K4 can block PRC2 action and can, hence, antagonize PcG and counteract gene repression [44]. Our study showed that the levels of PcG (Ezh2, Bmi-1, Eed) and TrxG (Mll, Trx) were significantly changed in aging HSPCs and the changes were accompanied by obvious aging manifestations. It meant that the balance of the TrxG/PcG system in HSPC was affected in the aging process, so HSPC could not remember their own mission to continue differentiating into mature blood cells, hence, caused the aging of HSPC.

Furthermore, Western blot with anti-mouse H3K27me3 McAb and H3K4me3 McAb showed that aging HSPCs had significantly lower levels of H3K27me3 and H3K4me3 compared with young HSPCs. As Petruk $\mathrm{S}$ noted in his study, genetically, mutations in trxG and PcG genes can antagonize each other's function, whereas mutations of genes within each group have synergistic effects [45]. In our study, most of PcG and TrxG proteins were downregulated, thereby we speculated it suppressed the levels of H3K27me3 (by PcG) and H3K4me3 (by TrxG). The data also implied that the regulating effects of PcG/TrxG on the target genes may be mediated by H3K27me3 (by PcG) and H3K4me3 (by TrxG) and need further validation in our study.

About the target genes of PcG/TrxG, Hox genes were reported more frequently. Our ITRAQ STRING data 
A

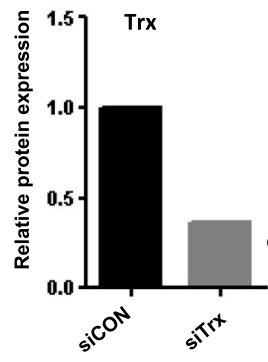

C

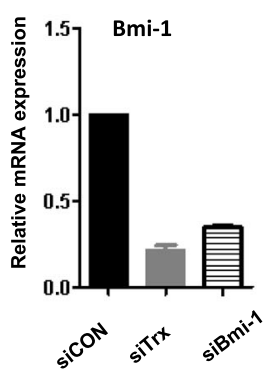

G

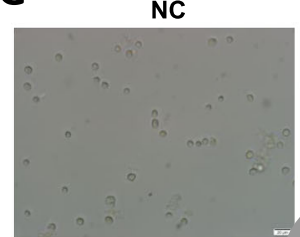

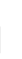

NC

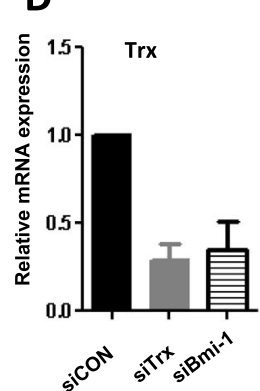

E

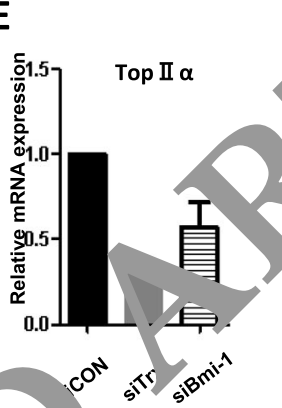

$F$
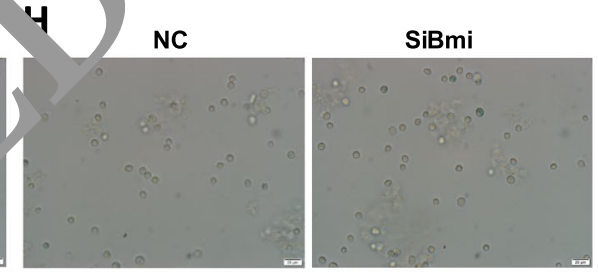

J

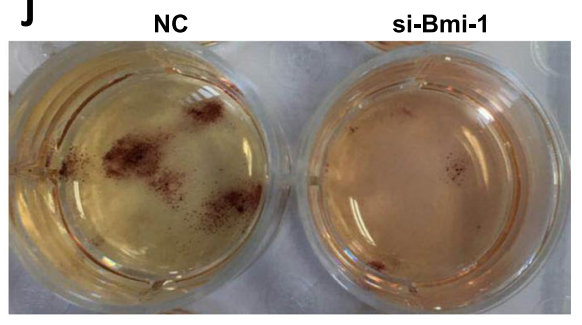

Fig. 7 Bmi-2 and Trx were mportant members of PCG/TrxG protein and knocking down Bmi-1/Trx downregulated TOPOIla/UHRF1 expression. a, b HSPCs ro 4 veek- Id mice were transfected with Bmi-1-siRNA and Trx-siRNA at $48 \mathrm{~h}$. Bmi-1 gene expression (b, c) and Trx gene expression (a, d) wre vali ted oy real-time PCR and WB analysis. mRNA expression of TOPOlla (e) and UHRF1 (f) decreased significantly in the Bmi-1 or the Tr knoc ed dow group. SA- $\beta$-gal-stained cells increased in the Bmi-1 or the Trx knocked down group, but there was no significant difference (n). corming ability of HSPCs significantly decreased in the Bmi-1 (j) or the Trx (i) knocked down group compared with the contro roup

hinted that the common target genes for PcG and TrxG were UHRF1 and TOPOII $\alpha$, we did further validation with siRNA and Chip-PCR. UHRF1 (ubiquitin-like with PHD and ring finger domains 1), also known as $90 \mathrm{kDa}$ inverted CCAAT box binding protein (ICBP90) or nuclear phosphoprotein 95 (NP95). UHRF1 controlled the self-renewal versus differentiation of HSCs by epigenetically regulating cell-division modes, suggesting that UHRF1 could affect HSPCs' fate [46]. Topoisomerase (TOPO) is an enzyme that can cut DNA at a particular point to unravels the DNA twist and relieves the DNA supercoil nature. It plays an essential role during DNA replication. TOPOII (topoisomerase II) catalyze a transient double-strand DNA break, which allows the passage of another DNA duplex through the break before the strands are resealed. There are two isoforms of mammalian TOPOII, TOPOII $\alpha$ and TOPOII $\beta$. The study of hematopoietic toxicity suggested that the level of TOPOII $\alpha$ was decreased in bone marrow mononuclear cells of hematotoxic mice, accompanied by reduced acetylation of histone $\mathrm{H} 4$ and histone $\mathrm{H} 3$ on TOPOII $\alpha$ promoter [47]. The previous study also demonstrated 
that TOPOII $\alpha$ represents the target enzyme for hematological anticancer drugs, including for leukemias and lymphomas [48]. These studies hinted the important roles of TOPOII $\alpha$ and UHRF1 in anti-damaged of HSC/ HSPC. In the present study, the levels of TOPOII $\alpha$ and UHRF1 were both significantly downregulated in the aging group. RNA interference on Trx in TrxG or Bmi-1 in PcG downregulated the gene expressions of UHRF1 and TOPOII $\alpha$. Meanwhile, it inhibited the colonyforming ability of HSPC. The results not only further indicated TOPOII $\alpha$ and UHRF1 were the target genes of Bmi-1 or Trx that was important PCG/TrxG proteins in HSPCs, but also hinted the role of TOPOII $\alpha /$ UHRF1 in anti-damaged of HSPC, it is worthy of verification.

Based on our hypothesis that TOPOII $\alpha$ and UHRF1 were the target genes of PCG/TrxG in the process of HSPC aging, we need to know if UHRF1 and TOPOII $\alpha$ were methylated by $\mathrm{H} 3 \mathrm{~K} 4 \mathrm{me} 3$ or $\mathrm{H} 3 \mathrm{~K} 27 \mathrm{me} 3$ that was downregulated by TrxG/PCG. CHIP-PCR assay showed that the H3K4me3 levels of TOPOII $\alpha$ and UHRF1 promoter were lower in aging HSPCs compared with young HSPCs, whereas there was no significant difference in the H3K27me3 levels of TOPOII $/$ UHRF1. We sr eculated that it may contribute to the decreased expro in of TOPOII /UHRF1 in aging HSPCs $b$-cause H3K4me3 positive regulation on target ge les ${ }^{12}$ ]. Petruk $\mathrm{S}$ noted in his study "no overall syn _rism or nagonism between the trxG and PcG pr teins and, instead, only subsets of trxG proteins act sy rrgisti ally" [45]. Consistent with his study, ou finding, uemonstrated UHRF1/TOPOIl $\alpha$ was regulated y me3 of TrxG.

\section{Conclusion}

In conclusion, ou worn roposed a quick and easy method of buil $\mathrm{An}_{\mathrm{L}}$ senesce ice HSPCs in vitro with 4week mice $\mathrm{u}^{\mathrm{l}} \mathrm{ich}$ can he used for experimental study of HSPC agi , fo recasted that can be used for preliminary screen drus of he hopathy. On the basis of this model and 00 prec $\mathrm{ng}$ work on naturally aged mice, we ma th maint that TrxG/PcG disequilibrium impaired cellula memory of HSPC, so that HSC/HSPC could not rememb er their own mission to continue differentiating into mature blood cells, then led finally to cause or aggravate the aging of HSPCs. Our studies further identified UHRF1/TOPOII as target genes of the TrxG/PcG system in the HSPC aging process. TrxG/PcG disequilibrium shown in this paper extended our understanding of the molecular mechanisms underlying HSPC senescence.

\section{Abbreviations}

HSPC(s): Hematopoietic stem and progenitor cell(s); MACS: Magnetic cell sorting; CFU: Colony forming unit; TEM: Transmission electron microscope; tBHP: Tert-butyl hydroperoxide hydroperoxide; PCG: Polycomb group: TrxG: Trithorax group; MNCs: Bone marrow mononuclear cells; Lin: Lineage;
IL3: Interleukin 3; IL6: Interleukin 6; SCF: Stem cell factor; SA- $\beta$ gal: Senescence-associated beta-galactosidase; RNA-seq: RNA sequencing; iTRAQ: Isobaric tags for relative and absolute quantification; ChIP: Chromatin immunoprecipitation; CFU-E: Colony-forming unit-erythroid; BFU-E: Burstforming unit-erythroid; CFU-GM: Colony-forming unit-granulocy' $c$, macrophage; CFU-G: Colony-forming unit-granulocyte; CFU-M: Cole t-form ing unit-macrophage; CFU-GEMM: Colony-forming unit-granulocyt, throic macrophage, megakaryocyte; CFU-pre-B: Colony-forming unit-pre GO: Gene Ontology; KEGG: Kyoto Encyclopedia of $G$ es and Genor es: MII: Mixed lineage leukemia; Ezh2: Enhancer of zeste h olog 2 3 mi-1: B cell-specific MLV integration site-1; Trx: Thiore coxIrm 1; Eea n' iyonic ectoderm development; Mel-18: Pcgf2 poly $\mathrm{mb}$ group rin tinger 2; Rae28: Phc1 polyhomeotic-like 1; UHRF1: E3 ub iitin-prote $n$ ligase UHRF1; TOPOlla: DNA topoisomerase 2-alpha 2K27 Tri ethylation of histone H3K27; H3K4me3: Trimethylation chisto H3K4

\section{Supplementary format n}

The online version intair supplementary material available at https:/doi. org/10.1186/s13287-

Addition. Fig. 1. The percentage of SA- $\beta$-gal stain-positive cells. The p rce itay of SA- $\beta$-gal stain-positive cells increased gradually at day $2,4,6$,

'itional fi 2: Fig. S2. The ultrastructure of HSPCs changed. The pho nicrographs of TEM showed that nuclear membrane, perinuclear cisteri e, chromatin edge, inclusion body in cytoplasm of HSPC changed. Dld rouse HSPC showed similar but less morphologic changes than in del HSPC.

Additional file 3: Fig. S3. Proteomics KEGG pathway analysis of differentially expressed proteins. (a,b), Pyruvate kinase were significantly increased and pyruvate dehydrogenase E1were reduced in the model cells. (c,d), Dkc1, GAR1, Nop10, Nog1 and ribosomal proteins in the ribosome-sized subunits also decreased significantly in the model cells. (e), U2AF1 (U2AF) 1 were significantly decreased in the model cells. ( $f$ ), Lysosomal related proteins such as Cathepsin, TPP1, lysosomal membrane protein LIMP, Iysosomal-associated membrane protein (LAMP), and ATPeV were significantly increased in the model cells.

Additional file 4: Table S1. Percentage of SA- $\beta$-Gal positive HSPCS (\% x $\pm \mathrm{s}, \mathrm{n}=3$ ).

\section{Acknowledgements}

We thank J.F.G. and M.K.H for critically reading the manuscript. We also acknowledge the efforts of many researchers, including the consortium members, who generated the foundational knowledge that made the program possible.

\section{Authors' contributions}

L.N.Z. supervised the entire study including the experimental design and data analysis and wrote the manuscript. Y.P.D. conducted the experiments. W.X.Z. analyzed the data. L.W.F. mainly funded the project and guided some experiments. C.N.G. mainly takes charge of the major revision and minor revision. All authors interpreted the data and approved the final manuscript.

\section{Funding}

This research was sponsored by the National Natural Science Foundation of China (No. 82074274, No. 81403279) and the Science and Technology Commission of Shanghai Municipality (No. 18411951400, No. 19495810200).

\section{Availability of data and materials}

All data needed to evaluate the conclusions in the paper are present in the paper and/or the materials cited herein. Additional data related to this paper may be requested from the authors. 


\section{Declarations}

\section{Ethics approval and consent to participate}

All the animal experiments were performed following ethical permission from the Animal Care and Use Committee of Shanghai University of Traditional Chinese Medicine (PZSHUTCM200717008).

\section{Consent for publication}

Not applicable.

\section{Competing interests}

The authors declare that they have no competing interests.

\section{Author details}

'Institute of Basic Medicine, Shanghai University of Traditional Chinese Medicine, 1200 CaiLun Ave., Pudong, Shanghai 201203, China. ${ }^{2}$ Department of Emergency and Critical Care Medicine, Shanghai Changzheng Hospital, The Second Military Medical University, Shanghai, China. ${ }^{3}$ Department of Neurology, Shanghai General Hospital, Shanghai Jiao Tong University School of Medicine, Shanghai, China.

\section{Received: 16 February 2021 Accepted: 10 June 2021} Published online: 09 August 2021

\section{References}

1. Luis TC, Tremblay CS, Manz MG, North TE, King KY, Challen GA Inflammatory signals in HSPC development and homeostasis: too much of a good thing? Exp Hematol. 2016;44(10):908-12. https://doi.org/10.1016/j. exphem.2016.06.254

2. Abkowitz JL, Catlin SN, McCallie MT, et al. Evidence that the number of hematopoietic stem cells per animal is conserved in mammals. 100(7):2665-7. https://doi.org/10.1182/blood-2002-03-0822.

3. Geng S, Mu XY, Chen XB, Hou JY, Jia DY, Xu CY, Wang YP. XY, Chen XB, Hou JY, Ja DY, XuCY, Wang Ypif progenitor cell senescence. Stem Cells Int. 2015;201 , 120.

4. Li J, Cai D, Yao X, Zhang Y, Chen L, Jing P, et al. P btective effect of Ginsenoside Rg1 on hematopoietic stem/progen r cells throl ugh attenuating oxidative stress and the Wnt/beta-cato sian ig pathway in a mouse model of d-galactose-induced ing. Int J Mur-cl. 2016:17(6):849.

5. Liran I. Shlush. Age-related clonal hematc Dor olnod. 2018;131:496-504.

6. Lee J, Yoon SR, Choi I, Jung H. Causes and $m$ char sms of hematopoietic stem cell aging. Int J Mol Sci. 201:20(6).

7. de Haan G, Lazare SS. Agin f her atopoiet _ stem cells. Blood. 2018; 131(5):479-87. https://driorg / 102, d-2017-06-746412.

8. Rando TA. Stem cells agelng an e quest for immortality. Nature. 2006; 441(7097):1080-6 it , /doi.org/1 .1038/nature04958.

9. Flores-Guzman P, Fernaı z-Sanchez V, Mayani H. Concise review: ex vivo expansion cord blood-dt ed hematopoietic stem and progenitor cells: basic pri "oles, perimental approaches, and impact in regenerative medicine. Cells ansl Med. 2013;2(11):830-8. https://doi.org/10.5966/

10. Sach Bakker S, Mohrin M, Conroy PC, Pietras EM, Reynaud D, et al. ess is a potent driver of functional decline in ageing hat topoietic stem cells. Nature. 2014;512(7513):198-202. https://doi.org/1 0.1038 ature 13619

11. Meng A, Wang $Y$, Van Zant G, Zhou D. lonizing radiation and busulfan induce premature senescence in murine bone marrow hematopoietic cells. Cancer Res. 2003;63(17):5414-9.

12. Shao L, Feng W, Li H, Gardner D, Luo Y, Wang Y, et al. Total body irradiation causes long-term mouse BM injury via induction of HSC premature senescence in an Ink4a- and Arf-independent manner. Blood. 2014;123(20): 3105-15. https://doi.org/10.1182/blood-2013-07-515619.

13. Tang YL, Zhou Y, Wang YP, Wang JW, Ding JC. SIRT6/NF-kappaB signaling axis in ginsenoside Rg1-delayed hematopoietic stem/progenitor cell senescence. Int J Clin Exp Pathol. 2015;8(5):5591-6.

14. Kamminga LM, de Haan G. Cellular memory and hematopoietic stem cell aging. Stem Cells. 2006;24(5):1143-9. https://doi.org/10.1634/stemcells.20050345.

15. Brand M, Nakka K, Zhu J, Dilworth FJ. Polycomb/Trithorax antagonism: cellular memory in stem cell fate and function. Cell Stem Cell. 2019;24(4): 518-33. https://doi.org/10.1016/j.stem.2019.03.005.
16. Tagoh H, Melnik S, Lefevre P, Chong S, Riggs AD, Bonifer C. Dynamic reorganization of chromatin structure and selective DNA demethylation prior to stable enhancer complex formation during differentiation of primary hematopoietic cells in vitro. Blood. 2004;103(8):2950-5. https://doi. org/10.1182/blood-2003-09-3323.

17. Burrill DR, Silver PA. Making cellular memories. Cell. 2010;14 1):13https://doi.org/10.1016/j.cell.2009.12.034.

18. Dong $Y$, Lian $X, X u Y, H u H$, Chang $C$, Zhang H, et al Hematopo $\mathrm{cm} /$ progenitor cell senescence is associated with alte expression pr illes of cellular memory-involved gene. Biosci Rep. 2018;38(t tps://c i.org/10.1 042/BSR20171589.

19. Ringrose $L$, Paro R. Epigenetic regulation f cellular mem s y by the Polycomb and Trithorax group proteins. nu Rev $G$ het. 2004;38(1):413-43. https://doi.org/10.1146/annurev.G-38.0

20. Wei $Y$, Zeng B, Zhang $H$, Chep Wu Wang N, et al. iTRAQ-based proteomics analysis of sery proteins in ar rats treated with sodium fluoride: insight into the oote al mechan $\mathrm{sm}$ and candidate biomarkers of fluorosis. Int J Mol Sci. 20:6;17( h httns://doi.org/10.3390/ijms17101644.

21. Baker DJ, Sedivy "vi. bing the d pths of cellular senescence. J Cell Biol. 2013;202(1):11 https/doi.ora/10.1083/jcb.201305155.

22. Bassaneze V, Miya a A $A_{\text {, }}$, neger JE. Chemiluminescent detection of senescence-associate 63. httk org/10.1,07/978-1-62703-239-1_9.

23. Merkel $\mathrm{k}+\mathrm{S}^{+}$an and aging processes in human menisci surfaces. A combinat n electron optic study with the transmission and the scanning electron m roscope. Verh Dtsch Ges Pathol. 1978;62:482.

24. ng YX, Sun Y, Xiang XR. Transmission electron microscopic observation on he liver and cerebral cortex in aging mice treated with Sijunzi de oction. Zhongguo Zhong Xi Yi Jie He Za Zhi. 1995;15(6):359-61. no SJ, Moon JS, Lee CM, Choi AM, Stout-Delgado HW. Glucose transporter 1-dependent glycolysis is increased during aging-related lung fibrosis, and phloretin inhibits lung fibrosis. Am J Respir Cell Mol Biol. 2017:56(4):521-31. https://doi.org/10.1165/rcmb.2016-02250C.

26. Obeng EA, Chappell RJ, Seiler M, Chen MC, Campagna DR, Schmidt PJ, et al. Physiologic expression of Sf3b1(K700E) causes impaired erythropoiesis, aberrant splicing, and sensitivity to therapeutic spliceosome modulation. Cancer Cell. 2016;30(3):404-17. https://doi.org/10.1016/j.ccell.2016.08.006.

27. Inoue D, Bradley RK, Abdel-Wahab O. Spliceosomal gene mutations in myelodysplasia: molecular links to clonal abnormalities of hematopoiesis. Genes Dev. 2016;30(9):989-1001. https://doi.org/10.1101/gad.278424.116.

28. Chambers SM, Shaw CA, Gatza C, Fisk CJ, Donehower LA, Goodell MA Aging hematopoietic stem cells decline in function and exhibit epigenetic dysregulation. PLoS Biol. 2007;5(8):e201, doi: https://doi.org/10.1371/journal. pbio.0050201

29. Le Bousse-Kerdiles MC, Smadja-joffe F, Fernandez-Delgado R, Jasmin C. Organization of haematopoietic stem cells and their relationship to mastocytopoiesis. Ann Inst Pasteur Immunol. 1986;137D(2):187-99.

30. López C, Zamorano P, Teuber S, Salas M, Otth C, Hidalgo MA, et al. Interleukin-3 prevents cellular death induced by oxidative stress in HEK293 cells. J Cell Biochem. 2017;118(6):1330-40. https://doi.org/10.1002/jcb.25790.

31. CatherineFrelin YO, Ruston J, et al. Grb2 regulates the proliferation of hematopoietic stem and progenitors cells. Biochim Biophys Acta Mol Cell Res. 2017;1864(12):2449-59.

32. Lee BB, Choi A, Kim JH, Jun Y, Woo H, Ha SD, et al. Rpd3L HDAC links H3K4me3 to transcriptional repression memory. Nucleic Acids Res. 2018; 46(16):8261-74. https://doi.org/10.1093/nar/gky573.

33. Benayoun BA, Pollina EA, Ucar D, Mahmoudi S, Karra K, Wong ED, et al. $\mathrm{H} 3 \mathrm{~K} 4 \mathrm{me} 3$ breadth is linked to cell identity and transcriptional consistency. Cell. 2015;163(5):1281-6. https://doi.org/10.1016/j.cell.2015.10.051.

34. Fontcuberta-PiSunyer M, Cervantes S, Miquel E, Mora-Castilla S, Laurent LC, Raya A, et al. Modulation of the endocrine transcriptional program by targeting histone modifiers of the H3K27me3 mark. Biochim Biophys Acta. 1861;2018:473-80

35. Vieira W, Sahin H, Wells K, McCusker C. Trimethylation of Histone 3 lysine 27 (H3K27me3) ChIP-PCR and transcriptional expression data of Ef1-alpha, cyp26A, HoxC10, HoxD10 and HoxD11 in the Xenopus XTC cell line. Data Brief. 2017;15:970-4. https://doi.org/10.1016/j.dib.2017.10.056.

36. Beerman I, Rossi DJ. Epigenetic regulation of hematopoietic stem cell aging. Exp Cell Res. 2014;329(2):192-9. https://doi.org/10.1016/j.yexcr.2014.09.013.

37. Buszczak M, Spradling AC. Searching chromatin for stem cell identity. Cell. 2006;125(2):233-6. https://doi.org/10.1016/j.cell.2006.04.004. 
38. Schuettengruber B, Bourbon HM, Di Croce L, Cavalli G. Genome regulation by Polycomb and Trithorax: 70 years and counting. Cell. 2017;171(1):34-57. https://doi.org/10.1016/j.cell.2017.08.002.

39. Radulovic V, de Haan G, Klauke K. Polycomb-group proteins in hematopoietic stem cell regulation and hematopoietic neoplasms. Leukemia. 2013;27(3):523-33. https://doi.org/10.1038/leu.2012.368.

40. Schnerch A, Lee JB, Graham M, Guezguez B, Bhatia M. Human embryonic stem cell-derived hematopoietic cells maintain core epigenetic machinery of the Polycomb group/Trithorax group complexes distinctly from functional adult hematopoietic stem cells. Stem Cells Dev. 2013;22(1):73-89. https://doi.org/10.1089/scd.2012.0204

41. Powis $G$, Mustacich $D$, Coon A. The role of the redox protein thioredoxin in cell growth and cancer. Free Radic Biol Med. 2000;29(3-4):312-22. https:// doi.org/10.1016/S0891-5849(00)00313-0.

42. Lund $\mathrm{AH}$, van Lohuizen M. Polycomb complexes and silencing mechanisms. Curr Opin Cell Biol. 2004;16(3):239-46. https://doi 016/j.ceb.2004.03.010.

43. Di Croce L, Helin K. Transcriptional regulation by Polycomb o oup prote Nat Struct Mol Biol. 2013;20(10):1147-55. https://doi.org/1 .10 nsmb.266

44. Geisler SJ, Paro R. Trithorax and Polycomb group-depena nt reg tion: a tale of opposing activities. Development. 2015;142/ (1):2076-87. htt, //doi. org/10.1242/dev.120030

45. Petruk S, Smith ST, Sedkov Y, Mazo A. Association ftrxG and PcG proteins with the bxd maintenance element depends on tra rint al activity. Development. 2008;135(14):2383-90. htt , niorg/10.1242/dev.023275.

46. Zhao J, Chen X, Song G, Zhang J, Liu H, L I X. Ontrols the selfrenewal versus differentiation of hematopo zic stern cells by epigenetically regulating the cell-division modes, roc Nat, A arad Sci U S A. 2017;114(2): E142-51. https://doi.org/10. 3/p 16120,7114

47. Shi Y, Qian S, Li J, Yu K "stono etylatıon modification of topoisomerase enzyme alpha prom regulatio 1 ors in patients with chronic benzene poisoning. Zhon rua Dong Wer Sheng Zhi Ye Bing Za Zhi. 2016;34(1): 8-12. https:// Norg/10.3, V/cona.j.jssn.1001-9391.2016.01.002.

48. Rossi E, Vil' anace V, Bassott G, Donato F, Festa A, Cengia G, et al. TOPOIl alpha anc 'ER-2, Meu'verexpression/amplification in Barrett's oesophagus, dysplasia an Jenoo icinoma. Histopathology. 2010;57(1):81-9. https://doi.

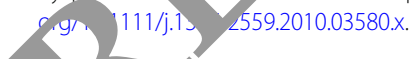

\section{Publı. er's Note}

Springer $N$ are remains neutral with regard to jurisdictional claims in published maps and institutional affiliations.

Ready to submit your research? Choose BMC and benefit from:

- fast, convenient online submission

- thorough peer review by experienced researchers in your field

- rapid publication on acceptance

- support for research data, including large and complex data types

- gold Open Access which fosters wider collaboration and increased citations

- maximum visibility for your research: over $100 \mathrm{M}$ website views per year

At $\mathrm{BMC}$, research is always in progress.

Learn more biomedcentral.com/submissions 